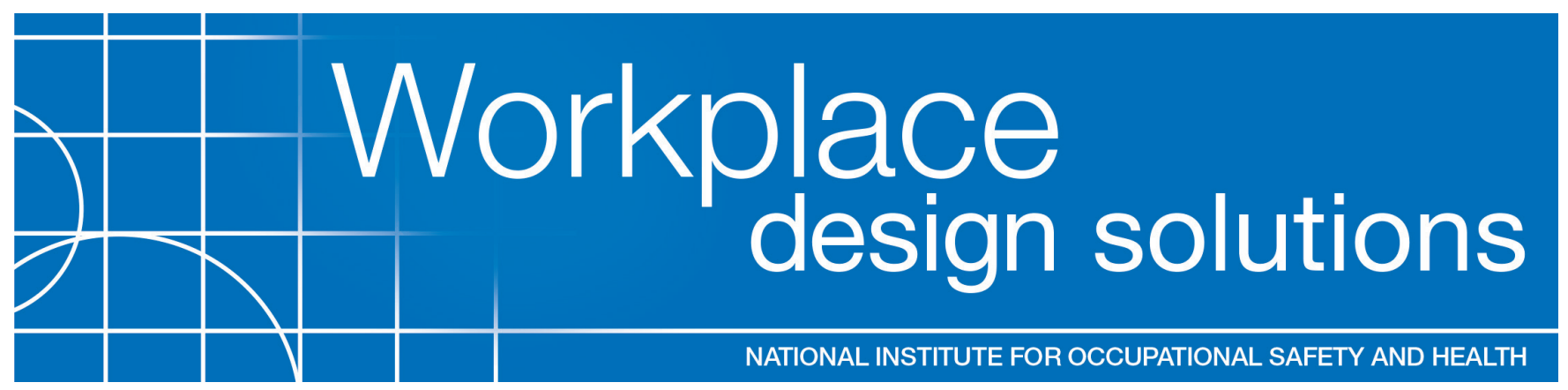

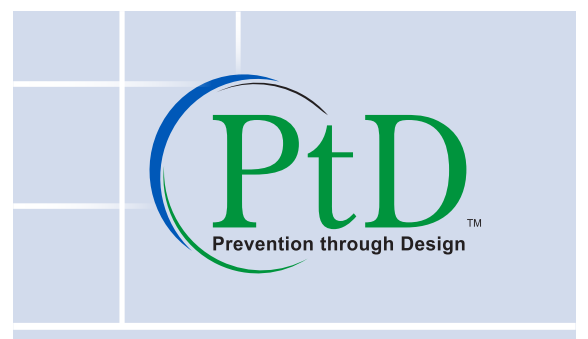

\section{Prevention through Design (PtD)}

PtD addresses worker exposure to hazards during the design stages of a project. For example, when a building or other structure is designed or redesigned, risks of fall-related injuries and fatalities to construction workers and users of the completed facilities could be minimized by following a PtD approach. NIOSH recommends that facility designers, owners, constructors, and safety and health professionals collaborate to perform one or more safety design reviews to explore and address hazards likely to occur over the life cycle of the facility.

This approach would incorporate safety features into the building's design, address fall hazards in construction plans, establish safety criteria for buying equipment, and communicate risks to building owners and facilities personnel [Behm 2005] rather than rely on other forms of protection such as personal protective equipment (PPE) or administrative controls.

\section{Contents}

- Description of Exposure

- Standards

- Design Solutions

- Cost Savings/Advantages of Permanent Features

- Case Study

- Recommendations

- Acknowledgments

- References

\title{
Preventing Falls from Heights through the Design of Embedded Safety Features
}

\section{Description of Exposure}

Construction is one of the most dangerous industries [Toole and Gambatese 2008], and falls are a frequent cause of fatal injuries in this industry. Of the 4,693 fatal work injuries that occurred in 2011, 553 (12\%) were the result of falls to a lower level. Fatal falls in construction accounted for $46 \%$ of all workrelated fatal falls in 2011 [BLS 2012]. OSHA estimates that each fall from an elevated position in construction (both fatal and nonfatal) costs between $\$ 50,000$ and $\$ 106,000$ [OSHA 2012]. Workers are at risk of falling during initial construction, and after completion during operation, maintenance, renovation, and demolition of buildings. Facility features associated with falls include floor and roof edges, elevated platforms, ledges, atria, skylights, machine rooms, and ladders and stairways. Falls can occur from temporary structures used in construction and maintenance such as scaffolds or ladders, or from permanent locations such as roofs.

\section{Standards}

OSHA Standard 29 CFR $^{*} 1926.502$ covers requirements for fall protection systems. One of the following is always needed to protect workers from falls:

- Job-built or commercially available guardrails that meet OSHA height and strength requirements [29 CFR 1926.502(b); Bobick et al. 2010].

- Properly designed anchor points with appropriate personal fall arrest systems and lifelines [Bobick et al. 2010].

- Other forms of fall protection such as safety netting [29 CFR 1926.502(c)].

The American National Standards Institute (ANSI) Standards [2007] ANSI Z359.0 through Z359.18 describe safety requirements for fall arrest systems.

ANSI Standard Z590.3 addresses prevention through design guidelines for hazards in the design and redesign processes.

${ }^{*}$ Code of Federal Regulations. See CFR in References.
DEPARTMENT OF HEALTH AND HUMAN SERVICES Centers for Disease Control and Prevention National Institute for Occupational Safety and Health 


\section{Design Solutions}

Designers should first consider the need for permanent fall protection features to protect construction workers, future occupants of facilities, and repair workers from fall hazards. A safety design review can help evaluate tasks that expose workers to hazards. Designers and safety and health professionals can then use the hierarchy of controls to select the most appropriate options to address the identified risks [Gambatese et al. 2005]. The hierarchy of controls for fall protection involves the following:

1. Eliminating or modifying the fall hazard itself is the preferred approach:

a. Adopting a building design involving a single level at grade rather than multiple levels at elevations would be the best way to eliminate the fall hazard.

b. Using parapet walls or permanent guardrails to separate the worker from the fall hazards would be the next preferred approach to eliminating the fall hazard.

2. The second option is providing a fall restraint system that secures the worker via an anchor point, connector, lanyard, and body harness to prevent the worker from reaching the fall hazard is the next option.

3. Installing a fall arrest system: this final option also uses an anchor point, connectors, lanyards, and body harnesses, but allows exposure to the fall and is then designed to stop the fall after it has begun.

Installing permanent fall protection features, depending on when they are installed during the construction process, may also be used to provide fall protection to workers during the construction phase.

A common requirement for all fall protection is the provision of suitably designed and installed anchor and support locations, which include a "secure connecting point or a terminating component of a fall protection system or rescue system capable of safely supporting the impact forces applied by a fall protection system or anchorage subsystem" [ANSI/ASSE 2011]. For many types of commercial and institutional buildings, equipment could be permanently embedded into steel or concrete parts of a building and used to set up fall protection systems.
These embedded safety features could be used to prevent falls during construction and building maintenance after construction. Embedded features can include concrete straps, anchor points for use with appropriate personal fall arrest systems and lifelines, or guardrail support [See NIOSH 2013 for details, diagrams, and photos of various design features].

Temporary safety features are not part of the building when it is completed. Permanent features are part of the building when it is completed. Planning for installation of permanent features is the preferred approach and involves the architect and consulting engineers who design the building. The features provide protection for construction workers, operations and maintenance workers, and future construction workers doing renovation, refurbishment, disassembly, or modification.

The decision to include temporary features is made by the construction company's engineers and safety personnel. These provide benefits for the construction worker and are typically removed when construction is done. OSHA general construction regulations [29 CFR 1926 subpart M] state that fall protection is required at 6 feet for temporary or construction purposes. Different industries have other protective height requirements, and they can be found in the appropriate OSHA regulation.

\section{Embeds for guardrail support}

Steel embeds could be placed along concrete slabs so that guardrails could be installed at the edges of all floors during construction. Embeds provide a secure method of installing guardrails that is quicker to install compared with bolted guardrail systems. Embeds could be used for both temporary systems used during construction, or for permanent guardrail or parapet systems used for both construction, operations and maintenance, and other future life-cycle needs.

\section{Embedded roof anchor points}

Anchor points are needed when a personal fall restraint or personal fall arrest system is selected for fall protection. Several embedded anchor points can be installed so that they provide tie off points for attaching horizontal or vertical lifelines used for these systems. They should be independent of anchorage used to support or suspend platforms and capable of supporting at least 5,000 pounds [29 CFR 1926.502(d)(15)].

\section{Straps embedded in concrete}

Straps are installed before casting by attaching each strap to the reinforcement (e.g. steel rebar) that will be buried within a concrete column, beam, or slab. The other end of the strap and its connecting D-ring are left hanging, allowing workers to attach their personal fall protection harnesses or other personal safety equipment to the strap. D-rings and snap hooks must be able to support a 5,000 pound load [29 CFR 1926.502(d)(3) and 29 CFR 1926.502(d)(9)]. Straps should meet requirements for ANSI Standard Z359.1. The straps are typically removed after construction is finished, so this option is intended to provide temporary fall protection anchorage for construction workers.

The decision to add concrete embeds should be made during the conceptual design of a building. Only a minimal amount of additional design would be needed [NIOSH 2013]. Research is being conducted on the safety of new, environmentally friendly U.S. Green Building Council Leadership in Energy and Environmental Design (LEED) certified buildings, and recommendations have been proposed to include PtD safety features in these new designs. Including provisions during building construction to prevent injuries, illnesses, and fatalities among construction workers is an essential component of sustainable design [Harte 2009].

\section{Cost Savings/ Advantages of Permanent Features}

According to OSHA regulations, employers are the entities responsible for worker safety. Perhaps for this reason, architects and design engineers do not always consider hazards during the design phase of a construction project. It is also possible that building designers are wary of assuming responsibility for future safety incidents, however there is no research to suggest that building designers who consider safety are more subject to 
lawsuits than those who do not. Designers may also perceive that safety features take more time and money to install; designs are meant to be completed on schedule and cost effective for the owner [Gambatese et al. 1997; Gambatese et al. 2005; Toole and Gambatese 2008]. But having the fall safety features in the original design and permanently embedded in concrete has been shown to save money. Fall protection can be set up more efficiently using permanently installed features rather than the added costs associated with installing temporary fall protection each time there is a roof-related maintenance or renovation task [Gambatese et al. 1997]. As noted by Rajendran and Gambatese [2013], roof anchor points are generally low cost.

\section{Case Study}

The NIOSH Fatality Assessment and Control Evaluation (FACE) Program supports fatality investigation programs in several States. The following case from New Jersey illustrates the importance of correct installation and how embedded anchors might have prevented a fall.

A 51-year-old construction worker died after falling from the roof of an industrial warehouse under construction. He was wearing full protective equipment, including a harness and retractable lanyard connected to a temporary metal anchor installed as part of the construction fall protection system. The anchor was attached to the unsecured leading edge of the corrugated decking. When the anchor broke free, he fell 40 feet to the ground.

In addition to improper anchor plates and screws, another contributing factor to the fall was having the anchor plate mounted on an unsecured edge. If the anchor plate had been an embedded feature that was part of a permanent fall protection system, the anchor might not have broken free and caused the victim to fall to the ground [NJ DOH 2012].

\section{Recommendations}

Building owners and designers should take the following measures to prevent falls [NIOSH 2013; NYC DOB 2008; NJ Health 2012]:
- During retrofits, renovations, or new construction, perform a safety design review to identify and consider tasks that could involve fall hazards over the life cycle of the facility. Use Prevention through Design approaches to prevent fall hazards or to provide engineering features to provide fall protection.

- Consult with certified professional engineers to install new features or to retrofit older buildings with permanent embedded safety features.

- For new construction, an architect or structural engineer should prepare a drawing indicating the location of fall protection anchor points and their capacities for guiding construction and maintenance personnel.

- Ensure that a competent person ${ }^{\dagger}[29$ CFR 1926.32(f)] inspects the fall arrest system before and during installation.

- Have any existing concrete-embedded fall arrest systems field tested by a qualified testing entity to ensure that they are capable of withstanding intended loads.

- Ensure that a competent person inspects and evaluates the fall arrest systems regularly for damage.

- Ensure that no one uses the system before compliance with the conditions listed above.

\section{Acknowledgments}

This document was prepared by E. A. McKenzie, Jr., Division of Safety Research, Matt Gillen, Office of the Director, and Susan Afanuh, Education and Information Division, National Institute for Occupational Safety and Health.

† “Competent person” means one who is capable of identifying existing and predictable hazards in the surroundings or working conditions that are unsanitary, hazardous, or dangerous to employees, and who has authorization to take prompt corrective measures to eliminate them [29 CFR 1926.32(f)].

\section{References}

ANSI [2007]. Safety requirements for personal fall arrest systems, subsystems, and components. Standard Z359.1.

ANSI/ASSE [2011]. Prevention through design guidelines for addressing occupational hazards and risks in design and redesign processes. Standard Z590.3.

Behm M [2005]. Linking construction fatalities to the design for construction safety concept. Safety Sci 43:589-611. http://www.sciencedirect.com/science/article/pii/S0925753505000731.

BLS [2012]. Table A-9. Fatal occupational injuries by event or exposure for all fatal injuries and major private industry 1 sector, all U.S., 2011. Washington, DC: Bureau of Labor Statistics. http://www.bls. gov/iif/oshwc/cfoi/cftb0267.pdf.

Bobick TG, McKenzie, Jr, EA, Kau T-Y [2010]. Evaluation of guardrail systems for preventing falls through roof and floor holes. J Safety Res 41: 203-211.

CFR. Code of Federal regulations. Washington, DC: U.S. Government Printing Office, Office of the Federal Register.

Gambatese JA, Hinze JW, Haas CT [1997]. Tool to design for construction worker safety. J Arch Eng March:32-41.

Gambatese JA, Behm M, Hinze JW [2005]. Viability of designing for construction worker safety. J Constr Eng Manage September:1029-1036. http://faculty.kfupm. edu.sa/cem/jannadi/Viability-of-Designingfor-Construction-Worker-Safety.pdf.

Harte A [2009]. Safe and green building design. PtD in Motion Newsletter. July (5):9-10.

NJ DOH [2012]. Hispanic construction worker wearing fall protection dies after falling 40 feet from roof. Trenton, NJ: New Jersey Department of Health, Public Health Services branch, Division of Epidemiology, Environmental and Occupational Health, Occupational Health Surveillance Unit. http://www.cdc.gov/ niosh/face/stateface/nj/09NJ099.html.

NYC DOB [2008]. Regulatory Notice: new protocols for existing and new concreteembedded fall arresting systems. New York City Department of Buildings. http:// www.nyc.gov/html/dob/downloads/pdf/regulatory_fall_arrest_061308.pdf.

NIOSH [2013]. Architectural design and construction: instructor's manual. 
Cincinnati, OH: U.S. Department of Health and Human Services, Centers for Disease Control and Prevention, National Institute for Occupational Safety and Health. http://www.cdc.gov/niosh/ docs/2013-133.

OSHA [2012]. Workers' compensation costs of falls in construction. Washington, DC: U.S. Department of Labor, Occupational Safety and Health Administration. http://www.osha.gov/dcsp/products/topics/businesscase/costs.html.

Rajendran S, Gambatese JA [2013]. Risk and financial impacts of prevention through design solutions. Pract Period Struct Des Constr 18(1):67-72.

Toole TM, Gambatese J [2008]. The trajectories of Prevention through Design in construction. J Safety Research 39:225-230. http://www.cdc.gov/niosh/topics/ptd/pdfs/Toole.pdf. CFR. Code of Federal regulations. Washington, DC: U.S. Government Printing Office, Office of the Federal Register. http://www.osha.gov/ pls/oshaweb/owadisp.show_document?p_ id $=10758 \&$ \&_table $=$ STANDARDS.

Gambatese JA, Hinze JW, Haas CT [1997]. Tool to design for construction worker safety. J Arch Eng March:32-41.

Gambatese JA, Behm M, Hinze JW [2005]. Viability of designing for construction worker safety. J Constr Eng Manage September:1029-1036. http://faculty.kfupm. edu.sa/cem/jannadi/Viability-of-Designingfor-Construction-Worker-Safety.pdf.

Hsaio H, Simeonov P [2001]. Preventing falls from roofs: a critical review. Ergonomics 44(5):537-561.

ICC [2012]. International Building Code. International Code Council, Standard 714.1.

NIOSH [1997]. Project engineer dies in fall from roof in Massachusetts. Cincinnati, OH: U.S. Department of Health and Human Services, Centers for Disease Control and Prevention, National Institute for Occupational Safety and Health, MA FACE 97-MA-044-01. http://www.cdc.gov/ niosh/face/stateface/ma/97ma044.html.

NIOSH [2000]. Worker deaths by falls: a summary of surveillance findings and investigative case reports. By Braddee RW, Hause MG, Pratt S. Cincinnati, OH: U.S. Department of Health and Human Services, Centers for Disease Control and Prevention, National Institute for Occupational Safety and Health, DHHS (NIOSH) Publication No. 2000-116. http://www.cdc.gov/niosh/docs/2000-116/ pdfs/2000-116.pdf.

NIOSH [2013]. Architectural design and construction: instructor's manual. Cincinnati, OH: U.S. Department of Health and Human Services, Centers for Disease Control and Prevention, National Institute for Occupational Safety and Health, DHHS (NIOSH) Publication No. 2013-133. http://www.cdc.gov/niosh/ docs/2013-133.

OSHA [2012]. Workers' compensation costs of falls in construction. Washington, DC: U.S. Department of Labor, Occupational Safety and Health Administration. http://www.osha.gov/dcsp/products/topics/businesscase/costs.html.

OSHA Alliance Program [2010]. Construction workplace design solutions: specify sufficient wall height to allow parapets to function as fall prevention. OSHA Alliance Program Construction Roundtable http://www.designforconstructionsafety.org/ Documents/Parapets_rev9.doc.

Pupkin A [2013]. Parapet roofs. Ezine Articles. August 15. http://ezinearticles. com/?Parapet-Roofs\&id=7937534.

Rajendran S, Gambatese JA [2013]. Risk and financial impacts of prevention through design solutions. Pract Period Struct Des Constr 18(1):67-72.

Toole TM, Gambatese J [2008]. The trajectories of Prevention through Design in construction. J Safety Research 39:225-230. http://www.cdc.gov/niosh/ topics/ptd/pdfs/Toole.pdf.

\section{For More Information}

The information in this document is based on research related to Prevention through Design (PtD) initiatives. More information about PtD is available on the NIOSH website at http://www.cdc.gov/niosh/topics/PtD.

More information about fall injury prevention can be found at:

- http://www.cdc.gov/niosh/topics/falls

More information about the NIOSH FACE Program can be found on the NIOSH website at:

- http://www.cdc.gov/niosh/face

- Click here for a list of NIOSH FACE Reports related to construction falls.

- Click here for a list of State FACE Reports related to construction falls.

- Click here for a list of NIOSH FACE Reports related to PtD.

To obtain information about other occupational safety and health topics, contact NIOSH at:

Telephone: 1-800-CDC-INFO (1-800-232-4636)

TTY: 1-888-232-6348 • CDC INFO: www.cdc.gov/info

or visit the NIOSH website at www.cdc.gov/niosh
For a monthly update on news at NIOSH, subscribe to NIOSH eNews by visiting www.cdc.gov/niosh/eNews.

Mention of any company or product does not constitute endorsement by NIOSH. In addition, citations to websites external to NIOSH do not constitute NIOSH endorsement of the sponsing organizations or their programs or products. Furthermore, NIOSH is not responsible for the content of these websites.

This document is in the public domain and may be freely copied or reprinted. NIOSH encourages all readers of the Workplace Design Solutions to make them available to all interested employers and workers.

As part of the Centers for Disease Control and Prevention, NIOSH is the Federal agency responsible for conducting research and making recommendations to prevent work-related illness and injuries. 